\title{
Article
}

\section{Biological attacks on underground hydroelectric pump storage power stations}

\author{
Pavlo Anakhov ${ }^{1, *}$ and Viktoriia Zhebka ${ }^{2}$
}

\author{
${ }^{1}$ Department of Infrastructure Systems, National Power Company "Ukrenergo", 01032 Kyiv, Ukraine; \\ anakhov@i.ua \\ ${ }^{2}$ Department of Telecommunication Systems and Networks, State University of Telecommunications, 03680 \\ Kyiv, Ukraine; viktoria_zhebka@ukr.net \\ *Correspondence: anakhov@i.ua
}

\begin{abstract}
Studies have shown the unconditional danger of biological attacks on underground hydroelectric pumped-storage power stations. A hypothetical list of biological damage to water conduits and dams is determined. Relevant predictions are given, as well as accident events of hydraulic structures are described. A universal scheme for the application of hazard protection measures, which can be comprehensive, has been developed. Praemonitus praemunitus precautions should be taken.
\end{abstract}

Keywords: dam; hazard protection measure; water conduit

\section{Introduction}

The attractiveness of using abandoned mines in the construction of underground hydroelectric pumped-storage power stations (UHPSPS) consists in reduction or exception of reservoir preparation works. However, there are doubts about the safety of this innovative technology.

Firstly, the water pumped to the upper reservoir is aerated, and its initial chemical composition evolves to be in equilibrium with the atmosphere leading to an increase of $\mathrm{pO}_{2}$ (power of hydrogen) and associated chemical reactions. In addition, this water is released into the underground reservoir and may react with the surrounding fractured medium and with the water occupying the reservoir. This may induce the deposition or dissolution of minerals and the associated impacts, e.g., reduction or increase in $\mathrm{pH}$. In the specific case of abandoned coal mines, where sulfides are common, an increase of $\mathrm{pO}_{2}$ in the upper reservoir may induce sulfide oxidation when the water is released in the underground reservoir. This fact would lead to very low $\mathrm{pH}$ values (i.e., acidification) and then affect the surrounding groundwater quality through the infiltration exchange fluxes between the underground reservoir and the surrounding geological layers $[1,2]$.

Secondly, the construction of UHPSPS requires the use of a lower underground reservoir in the form of drifts (horizontal underground mine). This could lead to problems in the discharge of water from the turbine due to the resistance implied by the lower reservoir, since it is not at atmospheric pressure. This resistance, in case of being high, could require a higher pressure for the turbine to complete the filling of the tunnel network [3].

Thirdly, at the end of the drift, the total reflection of the falling wave occurs. In theory, the waves double at those positions [4]. Consider that in the wet liquidation of mines, in which the volume produced is filled with water, a fractured-reservoir array is formed; it acts as a single fractured zone. Normal fluctuations of the water masses can contribute to increasing the seismicity of the created depression zone [5].

Current global warming is one of the factors that accelerates the invasive process. There is information on the "aggression" of invasive species in relation to local flora and fauna. The danger catalyst can be the anthropogenic impact, characterized by the 
promotion of climate change, artificial modification of the environment. There is evidence of attacks on communication cables, radioelectronic and electronic computing means that can cause invasive and indigenous populations of organisms or their communities, plants under global warming [6].

The aim of the paper is to study biological threats to underground hydroelectric pumped-storage power stations and possible bioaggression protection measures.

To achieve the aim, the following objectives must be accomplished:

1. To determine a list of threats;

2. To analyze their destructive effect;

3. To consider countermeasures.

\section{Method}

Fig. 1 shows the classification of biological damage to radioelectronic and electronic devices, Table 1 provides the explanation.

\begin{tabular}{|c|c|c|c|}
\hline \multicolumn{4}{|c|}{ Biodamages } \\
\hline \multirow{2}{*}{\begin{tabular}{|c|}
$\begin{array}{c}\text { 1. Mechanical failure } \\
\text { upon contact }\end{array}$ \\
\end{tabular}} & \multirow{2}{*}{$\begin{array}{c}\text { 2. Deterioration of opera- } \\
\text { tional parameters }\end{array}$} & 3. Biochemical destruction & 4. Biocorrosion \\
\hline & & \multirow{2}{*}{\begin{tabular}{|c|} 
3.1. Consumption during \\
nutrition
\end{tabular}} & \\
\hline 1.1. Collision & 2.1. Pollution & & \\
\hline 1.2. Gnawing & 2.2. Clogging & \multirow{2}{*}{$\begin{array}{l}\text { 3.2. Chemical effects of } \\
\text { released substances }\end{array}$} & \\
\hline 1.3. Destruction & 2.3. Fouling & & \\
\hline
\end{tabular}

Figure 1. Classification of biological damage to radioelectronic and electronic devices [7].

Table 1. Description of biological damage to radioelectronic and electronic devices [7].

\begin{tabular}{|c|c|}
\hline Bio damage type & Explanation \\
\hline \multicolumn{2}{|c|}{$\begin{array}{l}\text { 1. Mechanical failure upon contact (caused mainly by macroorganisms having } \\
\text { dimensions comparable to product dimensions): }\end{array}$} \\
\hline 1.1. Collision & birds with radio antennas \\
\hline 1.2. Gnawing & materials by rodents, or insects \\
\hline 1.3. Destruction & usually occurs in the process of feeding organisms \\
\hline 2.1. Pollution & $\begin{array}{l}\text { 2. Deterioration of operational parameters: } \\
\text { excretion of organisms and their metabolic products, the action of } \\
\text { which as a result of wetting with water or absorbing moisture from the } \\
\text { air leads to changes in product parameters }\end{array}$ \\
\hline 2.2. Clogging & $\begin{array}{l}\text { fungal and bacterial spores, plant seeds, parts fungal mycelium, bird } \\
\text { droppings, secretions of organisms, dying organisms }\end{array}$ \\
\hline 2.3. Fouling & $\begin{array}{c}\text { bacteria, fungi, sponges, mollusks and other organisms, which } \\
\text { increases metal corrosion }\end{array}$ \\
\hline
\end{tabular}

3. Biochemical destruction (caused mainly by microorganisms that are microscopic in size and invisible to the naked eye):

3.1. Consumption associated with preliminary chemical destruction of the starting during nutrition material of sometimes only one component (usually a low molecular weight compound, for example a plasticizer, stabilizer) by enzymes.

Such destruction opens the way for physicochemical corrosion, leads to a deterioration in the thermodynamic properties of the material and its mechanical destruction under the action of operational loads 3.2. Chemical chemical effect of metabolic products of microorganisms, which effects of released increases the aggressiveness of the environment, stimulates corrosion substances processes 4. Biocorrosion biocorrosion at the material-organism interface due to the action of 
amino and organic acids, as well as hydrolysis products; it is based on electrochemical processes of metal corrosion under the action of microorganisms

The presence of radioelectronic and electronic means in the HPSPS is the basis for using the classification of their biological damage in the analysis of damage to the pumped-storage station.

\section{Results}

\subsection{Biodamage to hydropower stations}

Assume the default unconditional biological vulnerability of radioelectronic and computing electronic means of hydropower stations and pay attention to biological damage to water conduits and dams. Some dam failures related to animal and plant activities are shown in Table 2.

Table 2. Dam failures (or near failure) related to animal and plant activities.

\begin{tabular}{cc}
\hline Case, Location, Date (M/Y) & Failure mode \\
\hline Sid White Dam, Near Omak, WA, USA, & Infiltration through animal burrows. \\
05/1971 [8] & Caused the dam to fail \\
Lower Jones Tract, California Delta, USA, & Infiltration and rodent activities \\
09/1980 [8] &
\end{tabular}

Iowa Beef Processor Waste Pond Dam, was overtopping due to heavy rainfall, the presence of tree roots 01/1993 [8] controlled infiltration through anima

Eleva Roller Mill, Wisconsin, USA, 03/1994

[9] in erosion

Lake Montonia Dam, North Carolina, USA, 02/1995 [9]

Oaklawn Pond Dam, Texas, USA, 11/1996

[9]

Piping; biological attack (i.e., bush, tree growth)

Infiltration was noted in three locations, in particular at the blown over tree under the root ball downstream of the drain pipe near the emergency spillway channel

The dam was severely damaged when strong winds uprooted several trees on the embankment. An inspection revealed that the upheaving of the root mass, aggravated by beavers damage, had left gaps in the crest and on the slopes of the dam

Pischieri Pond Dam, Cleveland, Ohio, USA, The dam was breached as a result of a void 1999 [8] in the body

Johnny Stewart Pond, Mississippi, USA, 02/2003 [9]

Infiltration along rotting tree roots developed into two major infiltration paths that were carrying material from within the dam

Foenna Stream, Sinalunga, Italy, 01/2006 [8] Porcupine burrow, internal erosion and dam subsidence

Truckee Canal, Fernley, Nevada, USA, 01/2008 [8]

Truckee Canal, Nevada, USA, 01/2008 [10]

Pin Oak levee, Winfield, Missouri, USA, 06/2008 [8]

Woody vegetation and animal burrows present

Breach of piping due to rodent activity Muskrat burrows 
Table 3 shows the description of biological damage to hydropower stations in the proposed form of Table 1.

Table 3. Biodamage to hydropower stations.

\begin{tabular}{l} 
Biodamage type $\quad$ Event that occurred / Threat of the event \\
\hline 1. Mechanical failure upon contact:
\end{tabular}

1.1. Collisions On August 7, 1978, about 25,000 $\mathrm{m}^{3}$ of logs and wood debris passed down the Melezza River to the Palagnedra Dam (Switzerland) and accumulated in the catchment area [11].

The dimensions comparable to the dimensions of gates and water conduits determine the danger of their destruction by a ram.

1.2. "Gnawing" Some dam failures caused by digging holes and seeping through tree and infiltration roots, associated with animal and plant activities, are shown in Table 2.

Examples of typical damage to earth dams by rodents are systematized and presented in the paper [8].

In the early 2000s, the United States conducted a survey of experts on the danger that vegetation poses to dams. The analysis of accidents revealed their causes [12]:

- $\quad$ uprooted trees that produce large voids and reduced freeboard; and/or reduced $x$-section for maintaining stability;

- decaying roots that create infiltration paths and internal erosion problems;

- $\quad$ obstructing emergency spillway capacity;

- falling trees causing possible damage to spillways and outlet facilities;

- $\quad$ inducing local turbulence and scouring around trees in emergency spillways and during overtopping;

- $\quad$ providing cover for rodent burrows;

- $\quad$ allowing roots to wedge into open joints and cracks in foundation rock along abutment groins and toe of embankment, thus increasing piping and leakage potential;

1.3. Destruction No incidents were detected

- root penetration of conduit joints and joints in concrete structures.

2. Deterioration of operational parameters:

2.1. Pollution Accumulation of biological pollutants can occur within an organism (for pathogens) or within a community (for genetically modified escapees or introduced invertebrates). The effects of introduced invasive species are sufficient to disturb an individual (internal biological contamination by parasites or pathogens), a population (by genetic changes) or a community (by increasing or decreasing the species complement) [13].

No damage to hydropower stations due to biopollution was detected.

2.2. Clogging Clogging is a ubiquitous phenomenon in nature and in such projects as tailings, dams. This seriously affects their safety. Comfortable 
conditions in the area, affected by power plants, attract periphyton colonies. Settlement and growth of populations are facilitated by changes in the hydrological regime, caused by the operation of dams and other hydraulic structures, increase in water temperature due to heat flows from power plants, enrichment of the reservoir with nutrients [14].

Reports of only jellyfish interfering with power station operation around the world [11, 15-17].

2.3. Fouling A significant number of events that are not provided by normal operation conditions of power stations is associated with fouling of gates and water conduits, trash grates, spiral chambers of turbines, other metal structures by plants and animals, which is a worldwide problem in marine systems $[9,18,19]$.

Bacterial and fungal slimes begin to develop on virtually any wetted surface within minutes of immersion. They reduce heat transfer in condensers, but they can also accelerate microbiologically induced corrosion of metals and concrete. Fungi are also involved in the biodegradation (rotting) of timber [20].

Research results of fouling organisms and degree of fouling, mitigation techniques are presented in the manuscript [17].

3. Biochemical destruction:

3.1. ConsumptionLivestock damage earthen dams by removing stabilizing vegetation. during nutrition External erosion occurs due to loss of vegetation [8, 12].

3.2. Chemical In many cases, microorganisms participate in stimulating the corrosion effects of released process. In aqueous environments, microorganisms tend to attach to substances the surface of solids and grow thereupon. This results in the formation of a uniform biofilm layer. The activity of microorganisms in the biofilm on the metal surface causes changes in the chemical composition of the environment and physical conditions at the metal-environment interface. The origination of heterogeneities of a physical and chemical nature at the metal-environment interface following biofilm formation is characterized by changes in the environment $(\mathrm{pH}$, oxidation ability, temperature, rate and character of flow, concentration of certain environmental components, etc.) [21].

4. Biocorrosion Biocorrosion on the metal surface is caused by microorganisms or their metabolic products. These can affect cathodic and anodic reactions, thus altering electrochemical processes at the biofilm-metal interface. It is reported that the National power company of South Africa, which provides $90 \%$ of the country's power needs, has identified cases of biological corrosion of carbon steel in water cooling systems at almost all of their power plants [22]. The paper [23] gives examples of detection of sulfate-reducing bacteria in metal structures of the Salto Pilão hydroelectric power station, Brazil. 
Microorganisms stimulate the corrosion process using environmental components or corrosion products during their metabolism. Examples include the ability of sulfate-reducing bacteria to exploit hydrogen and the ability of iron bacteria to oxidize $\mathrm{Fe}^{2+}$ to $\mathrm{Fe}^{3+}$, and thereby permanently support the corrosion process. Microorganisms can also evolve aggressive substances for metals (evolution of hydrogen sulfide by sulfate-reducing bacteria, production of sulfuric acid by sulfate-oxidizing bacteria, etc.). Only biofilm formation, enabling the formation of concentration corrosion cells, shall be considered as a physical change at the metal-environment interface [21].

\subsection{Protection of hydroelectric power plants against biodamage}

It must be admitted that natural disasters are often inevitable. So, optimization of their negative consequences becomes a practical task. Hazard reduction (protective measures) may include short-term hazard forecasting and warning; long-term forecasting and establishment of strict building codes in high-risk areas. The scheme of application of protection measures for radioelectronic and computing electronic means as a part of hydropower stations is the reason for using it in UHPSPS protection (Fig. 2).

\begin{tabular}{|c|c|c|c|}
\hline \multicolumn{4}{|c|}{ Short-term forecasting dangers } \\
\hline \multicolumn{2}{|c|}{ Warning } & \multicolumn{2}{|c|}{ Monitoring } \\
\hline \multicolumn{4}{|c|}{ Long-term forecasting. Hazard-resistant construction } \\
\hline \multirow{2}{*}{$\begin{array}{l}\text { Application of hazard- } \\
\text { resistant materials and } \\
\text { structures }\end{array}$} & \multicolumn{2}{|c|}{ Interception of hazard } & Removal from danger \\
\hline & $\begin{array}{l}\text { Passive (shielding } \\
\text { from danger) }\end{array}$ & $\begin{array}{l}\text { Active (counterac- } \\
\text { tion against danger) }\end{array}$ & $\begin{array}{l}\text { Maintenance systems } \\
\text { reconfiguration }\end{array}$ \\
\hline
\end{tabular}

Figure 2. Fig. 2: Scheme of application of hazard protection measures (from [24], modified).

The proposed scheme is designed for developing an action plan to prevent hazards of interferences, or at least reduce their negative consequences. Short-term hazard forecasting is performed to alert the public and collect data. The data are used in long-term forecasting. It is used in assessing risks and their acceptable levels to declare the safety of facilities, make decisions on their location and operation, develop prevention measures against accidents and prepare to respond to them. The list of protection measures includes:

- $\quad$ application of hazard-resistant materials and structures;

- hazard interception, which involves shielding the object or its most vulnerable and critical elements from danger, or shielding danger from the object, as well as counteracting the danger;

- maintenance systems reconfiguration (power supply, ventilation and air conditioning, fire alarm, fire extinguishing, warning, etc.).

The concept of reasonable sufficiency should be used as a basic criterion when developing a protection project. Its purpose is to ensure that the biological safety requirements for underground pumped-storage power stations are met with a minimum of funds and protection measures in the face of expected impact.

The development of protection measures against the effects of damaging factors depends on:

- $\quad$ the intensity of biological attacks in the appropriate area (zoning planning);

- $\quad$ estimation of objects vulnerability; 
- the cost of object protection equipment, as this can be an important criterion for complicating the protection scheme.

\section{Discussion}

The result of infiltration along the trees and shrubs roots is similar to the result of digging holes (gnawing). Examples show that biodamage is divided according to the origin - animal-related and plant-related.

No cases of destruction and contamination of water conduits and dams have been found, but this probability should not be ruled out. There are events in life that are hard to imagine. In Australia, for example, a transport drone delivering small goods was attacked by a crow.

The scheme of application of protection measures against biological hazards, which can be comprehensive, is developed. Hazards can be eliminated or reduced by several protection methods. Conversely, the same measures can be used to eliminate different hazards of both natural and anthropogenic origin.

The fundamental principle of bioethics "First, do no harm (Primum non nocere)" warns against ill-considered actions. Theoretical calculations on biological damage to underground pumped-storage power stations are one of the aspects of the comprehensive impact of innovative energy conservation technology on the environment. The proposed paper raises an issue that requires more detailed and inquisitive research.

Funding: This research received no external funding.

Institutional Review Board Statement: Not applicable.

Informed Consent Statement: Not applicable.

\section{References}

1. Pujades, E.; Orban, P.; Bodeux, S.; Archambeau, P.; Erpicum, S.; Dassargues, A. Underground pumped storage hydropower plants using open pit mines: How do groundwater exchanges influence the efficiency? Appl. Energy. 2017, 190, 135-146. Doi: 10.1016/j.apenergy.2016.12.093.

2. Pujades, E.; Jurado, A.; Orban, P.; Ayora, C.; Poulain, A.; Goderniaux, P.; Brouyère, S.; Dassargues, A. Hydrochemical changes induced by underground pumped storage hydropower and their associated impacts. J. Hydrol. 2018, 563, 927-941. Doi: 10.1016/j.jhydrol.2018.06.041.

3. Menéndez, J.; Loredo, J.; Galdo, M.; Fernández-Oro, J. M. Energy storage in underground coal mines in NW Spain: Assessment of an underground lower water reservoir and preliminary energy balance. Renew. Energy. 2019, 134, 1381-1391. Doi: 10.1016/j.renene.2018.09.042.

4. Pummer, E.; Schüttrumpf, H. Reflection Phenomena in Underground Pumped Storage Reservoirs. Water, 2018, 10, 504. Doi: 10.3390/w10040504.

5. Anakhov, P. V. Three-dimentional model of the deformation of structural Merian basin by standing waves. Geodynamics, 2019, 2, 48-53. Doi: 10.23939/jgd2019.02.048.

6. Anakhov, P.; Zhebka, V.; Grynkevych, G.; Makarenko, A. Protection of telecommunication network from natural hazards of global warming. East.-Eur. J. Enterp. Technol, 2020, 3/10, 28-37. Doi: 10.15587/1729-4061.2020.206692.

7. Gludkin, O. P. Metody i ustroystva ispytaniy RES $i$ EVS [Methods and devices for testing radio-electronic and electronic computing facilities]; Vysshaya shkola: Moscow, Russia, 1991. (In Russian).

8. Bayoumi, A.; Meguid, M. A. Wildlife and Safety of Earthen Structures: A Review. J. Fail. Anal. Prev , 2011, 11, 295-319. Doi: 10.1007/s11668-011-9439-y.

9. NPDP Dams Database. Stanford University. National Performance of Dams Program. Available online: http://npdp.stanford.edu/dams_database (accessed on 20 Sep. 2021).

10. Truckee Canal Failure on 5 January 2008. Investigative Evaluation Report; US Department of Interior: Bureau of Reclamation, 2008.

11. Wallerstein, N.; Thorne, C. R.; Abt, S. R. Debris Control at Hydraulic Structures in Selected Areas of the United States and Europe. Report CHL-97-4. London, 1997.

12. A Technical Manual on the Effects of Tree and Woody Vegetation Root Penetrations on the Safety of Earthen Dams; Marks, B. D.; Tschantz, B. A., Eds.; Marks Enterprises of NC, USA, 2002.

13. Elliott, M. Biological pollutants and biological pollution - an increasing cause for concern. Mar. Pollut. Bull., 2003, 46, 275-280. Doi:10.1016/S0025-326X(02)00423-X. 
14. Xu, Zengguang; Yang, Xuemin; Chai, Junrui; Qin, Yuan; Li, Yanlong. Permeability Characteristics of Tailings considering Chemical and Physical Clogging in Lixi Tailings Dam, China. J.Chem. 2016, 8147845. Doi: http://dx.doi.org/10.1155/2016/8147845.

15. Purcell, J. E.; Uye, S.-i.; Lo, W.-T. Anthropogenic causes of jellyfish blooms and their direct consequences for humans: a review. Mar. Ecol. Prog. Ser, 2007, 350, 153-174. Doi: 10.3354/meps07093.

16. Kopytko, N. Spineless attacks on nuclear power stations could increase. Bulletin of the atomic scientists. Available online: https:/thebulletin.org/2015/02/spineless-attacks-on-nuclear-power-plants-could-increase/ (accessed on 1 Sep. 2021).

17. Jenner, H. A.; Whitehouse J. W.; Taylor, C. J. L.; Khalanski, M. Cooling water management in European power stations Biology and control of fouling. Hydroecologie Appl., 1998, 10, 1-225. https://www.hydroecologie.org.

18. Hajare, V. S.; Husainy, A. S. N.; Jadhav, M. A.; Bardiya, S. G.; Nishandar, S. V. Evaluation of Bio-Fouling Effect in Cooling Tower by Chemical Treatment. Int. j. recent technol., 2019, 8, 374-378. Doi: 10.35940/ijrte.C4182.098319.

19. Liu, S.; Zhou, J.; Ma, X.; Liu, Y.; Ma, X.; Xia, C. Ecotoxicity and Preliminary Risk Assessment of Nonivamide as a Promising Marine Antifoulant. J. Chem., 2016, 2870279. Doi: http://dx.doi.org/10.1155/2016/2870279.

20. Turnpenny, A. W. H.; Coughlan, J. Ng. B.; Crews, P.; Bamber, R. N.; Rowles, P. Cooling Water Options for the New Generation of Nuclear Power Stations in the UK. Environment Agency, Bristol, 2017.

21. Novák, P. Environmental deterioration of metals. In Environmental Deterioration of Materials; Escrig, F., Managing Ed.; WIT Press: Boston, 2007, pp. 27-71.

22. Beech, I. B., Gaylarde, C. C. (1999). Recent advances in the study of biocorrosion - an overview. Revista de Microbiologia. Vol. 30, No. 3. P. 177-190.

23. Marangoni, P. R. D.; Robl, D.; Berton, M. A. C.; Garcia, C. M.; Bozza, A.; Porsani, M. V.; Dalzoto, P. do R.; Vicente, V. A.; Pimentel, I. C. Occurrence of Sulphate Reducing Bacteria (SRB) Associated with Biocorrosion on Metallic Surfaces in a Hydroelectric Power Station in Ibirama (SC) - Braz. Arch. Biol. Technol., 2013, 56, 801-809.

24. Anakhov, P.; Makarenko, A.; Zhebka, V.; Vasylenko, V.; Stepanov, M. Systematization of Measures on Lightning Protection of the Objects of Telecommunications Network. IJATCSE, 2020, 9, 7870-7877. Doi: 10.30534/ijatcse/2020/138952020. 